ISSN 2518-1521 (Online), ISSN 2226-2830 (Print) ВІСНИК МАРІУПОЛЬСЬКОГО ДЕРЖАВНОГО УНІВЕРСИТЕТУ СЕРІЯ: ІСТОРІЯ. ПОЛІТОЛОГІЯ, 2019, ВИП. 25

48. Чайковський А. С. Невідома війна (Партизанський рух в Україні 1941-1945 рр. Мовою документів, очима історика)/ А. С. Чайковський. - Київ :1994. - 255 с. ; Chaikovskyi A. S. Nevidoma viina (Partyzanskyi rukh v Ukraini 1941-1945 rr. Movoiu dokumentiv, ochyma istoryka) / A. S. Chaikovskyi. - Kyiv :1994. - 255 s.

Стаття надійшла до редакції 05.06.2019 р.

\title{
O. Verbovyi
}

STRUCTURE AND COMMAND STAFF OF SUMY PARTISAN ASSOCIATION (1941-1944)

The article is devoted to the process of formation of the Putivl combined partisan detachment (the Sumy Partisan Association, the 1st Ukrainian Partisan Division named after twice Hero of the Soviet Union, S. A. Kovpak), the formation and evolution of its structure. The creation and activity at the initial stage of the Putivl partisan detachments under the command of S. A. Kovpak and S. V. Rudnev, the Glukhiv partisan detachment under the command of P. L. Kulbaki, the Shalygin partisan detachment A. Ya. Saganiuk, Konotop partisan detachment F. E. Canavets, Kharkiv partisan detachment M. Y. Vorontsov and others is analyzed. The process of formation of the Putivl combined partisan detachment under the command of S. A. Kovpak-S. V. Rudnev-G. Ya. Bazimi and the accession of independent partisan detachments to its complement, formation of the structure and command staff of the united detachment and its units was traced. The evolutionary changes in the structure of the partisan association according to the conditions of conducting military operations are analyzed. The changes in staffing of the command personnel of the Sumy partisan association were researched.

The personnel and structural changes connected with the process of association reconfiguration in the 1st Ukrainian Partisan Division named after twice Hero of the Soviet Union S. A. Kovpak under the command of P.P.VershigoraM. O. Moskalenko- V. O. Voitsekhovich are determined. The influence of staffing of the command staff on the success of the combat activity of the unit is monitored.

Key words: Ukraine during World War II, partisan resistance movement, Putivl united partisan detachment, Sumy Partisan Association, 1st Ukrainian Partisan Division named after twice Hero of the Soviet Union S. A. Kovpak.

УДК 930:94(477+438)”19/20»

\section{Ю.О. Конарівська}

\section{ДІЯЛЬНІСТЬ «СОЮЗУ ПОЛЬСЬКОГО НАРОДУ» НА ПРАВОБЕРЕЖНІЙ УКРАЇНІ В ІСТОРИЧНІЙ ЛІТЕРАТУРІ СЕРЕДИНИ ХХ - ПОЧАТКУ ХХІ СТ.}

У статті аналізуються праці істориків XX- поч. XXI cm., у яких досліджуються форми і напрямки діяльності польського таємного товариства «Союз польського народу» на території Правобережної Украӥни, метою якого була підготовка місиевого населення, зокрема, селянства, яке складалося переважно з украӥнців, до повстання за відновлення Речі Посполитої у кордонах 1772 р., щуо означало і включення до ї̈ складу Правобережної Украӥни та Галичини. 
ISSN 2518-1521 (Online), ISSN 2226-2830 (Print)

ВІСНИК МАРІУПОЛЬСЬКОГО ДЕРЖАВНОГО УНІВЕРСИТЕТУ

СЕРІЯ: ІСТОРІЯ. ПОЛІТОЛОГІЯ, 2019, ВИП. 25

Зробивщи комплексний аналіз можна простежити, які завдання ставила перед собою наука, як змінювалися погляди істориків у різні періоди часу та відповідно до національності і наскільки дане питання є вивченим у польській, російській та украӥнській icmopiozpaфiï.

Ключові слова: “Союз польського народу», польський визвольний рух, Правобережна Україна, історична література $X X-$ поч. XXI cm.

DOI 10.34079/2226-2830-2019-9-25-37-49

Між Річчю Посполитою та Російською імперією, постійно точилася боротьба за включення українських земель до складу своєї держави. Поділи Речі Посполитої (1772, 1793,1795 р.) та включення українських земель до складу Російської імперії призвели до активізації польського національно-визвольного руху. Польські активісти, які проживали на Правобережжі закликали до боротьби і українське населення. Польський визвольний рух на Правобережжі активно підтримувався польською еміграцією. Боротьба між російською владою та польським населенням за українське Правобережжя велася не тільки зброєю, а точилася й інформаційна війна. Це яскраво простежується в історичній літературі, де автори намагалися довести приналежність цих земель до тієї чи іншої країни.

Яскравим прикладом бажання поляків поширити свій вплив на населення Правобережжя $є$ діяльність таємного товариства «Союзу польського народу» (Stowarzyszenie Ludu Polskiego). Це підпільна демократична організація, яка виникла у 1835 p і протягом 1838 - 1842 рр. була розгромлена. Більшість іiі членів, яких нараховувалося близько 1000, були арештовані. Ї̈ діяльність поширювалась, окрім етнічних польських земель і на терени Правобережної України, Галичини. Головними діячами були Шимон Конарський, Северин Гощинський (відомий поет, представник так званої «української школи» в польському романтизмі), Францішек Смолька.

Діяльність «Союзу польського народу» довгий час залишалася невисвітленою як в зарубіжній так і у вітчизняній історіографії. Діяльність організації була спрямована у першу чергу проти російської імперської влади, тому не в інтересах російської історичної науки було показувати масштабність діяльності товариства та політичну боротьбу імперії iз польським елементом на теренах Правобережної України. Тоді, як зарубіжні історики не мали доступу до архівних документів, а загальнодоступної інформації про товариство було занадто мало, тому ця проблема тривалий час залишалася поза увагою дослідників. Лише у XX столітті історики змогли розпочати наукові дослідження з даної теми.

Дана тема уже потрапляла в поле зору дослідників історіографів. Зокрема, польські, російські та українські автори вивчаючи цю проблему робили їі короткий історіографічний огляд.

Певний внесок по аналізу наукової літератури з даної теми зробила М. Хададова у своїх статтях «Діяльність «союзу польського народу» в Правобережній Україні в радянській історіографії 60-х років XX ст.» [16] та «Діяльність «Союзу польського народу» на Правобережній Україні в радянській історіографії» [17]. Усе ж проведені історіографічні дослідження 3 даної теми істориками, слід вважати недостатньо повними та цілісними. Тому аналіз наукової літератури і буде завданням даної публікації.

Грунтовні дослідження про діяльність «Союзу Польського народу» (надалі СПН) почали проводитись лише в середині XX ст. В першу чергу дослідження польських 
ISSN 2518-1521 (Online), ISSN 2226-2830 (Print) ВІСНИК МАРІУПОЛЬСЬКОГО ДЕРЖАВНОГО УНІВЕРСИТЕТУ СЕРІЯ: ІСТОРІЯ. ПОЛІТОЛОГІЯ, 2019, ВИП. 25

істориків активізувала сота річниця страти Ш. Конарського, палкого патріота Речі Посполитої, котрий виступав прикладом для поляків. По-друге, відкриття архівних документів, дало можливість історикам провести аналіз та відтворити цілісну картину тих подій. Слід зазначити, що дослідження про діяльність даної організації на Правобережній Україні з'явилися ще пізніше.

У 1936 р. на сторінках журналу «Kwartalnik historyczny» була надрукована робота Р. Роздольського «Do historii «Stowarzyszenia Ludu Polskiego» [25]. Вона складається із двох частин. У першій вміщено невідомі листи до Северина Гощинського, у другій зізнання Леслава Лукашевича. Тут опосередковано окреслено діяльність Ш. Конарського як організатора СПН.

Наприкінці 40-х років 3'явилась низка монографій польських істориків. В. Лукашевич [22] та Г. Мосьціцький [24] опублікували свої праці, присвячені Ш. Конарському та його конспіративній діяльності. С. Кєнєвіч [19] зупинився на утворенні СПН та діяльності «Головного збору», котрий 31836 р. через переслідування був змушений переїхати до Львова, та зв'язок його з усіма провінціями. Ці праці дали поштовх та стали основою для подальших досліджень польських та радянських авторів, котрі 3 відкриттям архівних документів більш деталізували, та змогли окреслити особливості діяльності СПН в кожному регіоні.

Важливий внесок по дослідженню даної проблеми зробив польський історик Б. Лопушаньський у монографії «Stowarzyszenie Ludu Polskiego (1835 - 1841)» [21]. Його робота присвячена утворенню, діяльності та викриттю «Союзу...», який розгорнув свою діяльність на території колишньої Речі Посполитої, і ставив собі за мету відродити іiі в кордонах 1772 р. Зокрема 4 розділ роботи присвячений утворенню та діяльності даного товариства на території Правобережної України та Білорусії, автор його називає «Stowarzyszenie ludu polskiego w zaborze rosyjskim» [21, c. 237].

Із українських земель, він описав діяльність товариства у Волинській, Подільській та Київській землях, останню називає Україною. Автор наголосив на тому, що розвиток союзу на українських землях мав дещо інший характер та відрізнявся від інших регіонів. Території, які увійшли до складу Російської імперії після поділів Польщі, він назвав найскладнішими для розвитку СПН [21, с. 237]. Це пов'язано головним чином із тим, що базою утворення товариства для Ш. Конарського мало слугувати «Товариство Філодемічне», яке ще називали «Віра, Надія, Любов» що діяло на Волині. Воно ще 3 1835 року розгорнуло свою активну діяльність. Проте погляди очільника «Товариства Філодемічного» К. Машковського були поміркованими, а радикальні погляди Ш. Конарського не набули широкого розповсюдження, тому що основну роль у створені союзу на Правобережжі відігравали польські магнати та шляхта, проти обмеження впливу яких виступив Ш. Конарський.

Основним завданням Ш. Конарського автор називає розширення товариства, приєднання до нього уже існуючих товариств, пошук засобів впливу на молодь та залучення до нього як найбільшої кількості різних верств населення. Ш. Конарський основну роль у польському визвольному русі надавав селянству. Автор вказав на провідних учасників, які відіграли основну роль у створенні та поширенні союзу, ксьондзів та молодь. У роботі висвітлені події, що пов'язані із стосунками СПН та студентами Київського університету, діяльність жіночого товариства, під проводом Сви Фелінської. Особливу увагу привертає той факт, який автор бере із щоденника Юстиніана Руціньського, що місцеві патріоти помітили в діях Ш. Конарського необережність та 
ISSN 2518-1521 (Online), ISSN 2226-2830 (Print)

ВІСНИК МАРІУПОЛЬСЬКОГО ДЕРЖАВНОГО УНІВЕРСИТЕТУ

СЕРІЯ: ІСТОРІЯ. ПОЛІТОЛОГІЯ, 2019, ВИП. 25

поспіх через засліплення вдачею, тому постановили аби він покинув край. Особливо на цьому наполягали представники Київщини [21, с. 270 - 271].

Головну ставку Ш. Конарський робив на молодь, тому автор описав діяльність студентів в Києві. На основі спогадів К. Машковського дав характеристику трьох основних регіонів, де СПН розгорнув свою діяльність. Це Волинь (населення підтримувало, але було бідним в матеріальних запасах), Поділля (найбільш різноманітне), Україна (люди пов'язані особистими обов'язками і не розвивали на потрібному рівні конспірацію, це і призвело до конфлікту з Ш. Конарським [21, с. 272]. Автор називає цю думку суб'єктивною. Недолік Ш. Конарського в тому, що він не враховував специфіку краю, орієнтувався не на ті елементи. Він опирався на балагулів, так звану золоту молодь, які захоплювалися справою конспірації, але не готові до будь-якої самовідданості, i вважали це лише пригодою. Як приклад автор наводить те, що головна зрада на Волині і Поділі пішла від А. Шашкевича керівника балагульщини [21, с. 273].

Наступним кроком у вичені цієї проблеми у польській літературі стала робота Є. Сковронка «Od konspiracji do kapitulacji» [27]. У роботі висвітлений матеріал, який охоплює події 30-х - 40-х років XIX ст., а саме події після Листопадового повстання по ті які передували весні народів. При викладі матеріалу про події на Правобережній Україні автор як джерела інформації використовував мемуарну літературу, щоденники Ж. Шчесни та I. Радзейовського, а також працю В. Лопушанського. Матеріал викладений в загальних рисах, автор підкреслив, що для проведення пропагандистської діяльність Ш. Конарський робив ставку на молодь, яка нав'язувала зв'язки з простим населенням під час різних свят, брала участь в забавах, вкладала у вухо нові пісні, в котрих пропагували нові ідеї в доступній мові [27, с. 27-28]. Автор показав наскільки важливим для діяльності СПН та Ш. Конарського було забезпечення пропагандистською літературою, через що останній намагався вирішити питання організації власної друкарні. Такі дії дали можливість владі натрапити на слід Ш. Конарського та арештувати його [27, с. 30]. Це в свою чергу призвело до викриття учасників «Союзу польського народу».

У радянській історіографії дослідження діяльності СПН розпочалося дещо пізніше. 3 24 по 27 січня 1961 р. в Москві відбулася перша координаційна нарада 3 актуальних проблем слов'янознавства, організована інститутом слов'янознавства АН СРСР. Координаційна нарада, на якій було присутні більше 500 чоловік з усього Радянського Союзу, була скликана 3 метою налагодження контактів між дослідниками та комплексного вивчення проблем історії слов'янства [6, с. 111]. На нараді визначені основні теми, які потребували дослідження. 3-поміж них революційний та національновизвольний рух слов'янських народів та взаємовідносини і різнопланові зв'язки слов'янських народів [6, с. 112, 114].

Після цього дослідники значну увагу приділили польському визвольному русі, зокрема діяльності Ш. Конарського та, очолюваного ним на Правобережній Україні, «Союзу польського народу». Адже дане товариство мало великий вплив серед польського населення на вказаних територіях.

Однією із перших з'явилася робота радянського історика С. Сімонова «Осередок «Союзу польського народу» в Київському університеті» [14]. Автор в загальних рисах окреслив діяльність студентів, що підтримували дух польськості в студентському колі, зокрема розповсюджували нелегальну польську літературу.

Поставлені нарадою завдання намагався виконати А.Смірнов у роботі «Революционные связи народов России и Польши: 30 - 60 годы XIX века» [15]. У цій 
ISSN 2518-1521 (Online), ISSN 2226-2830 (Print) ВІСНИК МАРІУПОЛЬСЬКОГО ДЕРЖАВНОГО УНІВЕРСИТЕТУ СЕРІЯ: ІСТОРІЯ. ПОЛІТОЛОГІЯ, 2019, ВИП. 25

праці автор описує діяльність Ш. Конарського, який після Листопадового повстання був змушений виїхати за кордон, де сформувались його погляди на подальший розвиток польського визвольного руху. Автор у дусі радянської історіографії відмітив: «Работы Конарского не оставляют сомнения, что в его лице польский народ видвинул убежденного сторонника революционного единения народов России и Польши, демократа, атеиста, врага феодального гнета, сторонника обеспечения крестьян землей» [15, с. 89]. Зокрема А. Смірнов зазначив, що Ш. Конарський у своїх національних поглядах припускався помилки, коли відносив білорусів, литовців і українців до різновидів польського народу [16, с. 91]. Також автор наголосив, що проблема полягала і в земельному питанні, адже шляхтичі ніколи не віддадуть своїх земель селянам і не зблизяться з народом [15, с. 97].

Намагаючись показати бажання Ш. Конарського зблизитись із селянством, на нашу думку, автор перебільшив, коли стверджував, що він уникав зупинок у дворянських маєтках, а здебілього йшов до селян, які його радо приймали та допомагали в подальшому пересуванні [15, с. 98 - 99]. Автор посилається на документ, який безпосередньо не свідчить, що Ш. Конарський ночував у селян, а говорить лише про те, що Ш. Конарський вів бесіди з народом у корчмах [15, с. 380]. Праця А.Смірнова містить значну кількість інформації, щодо організації товариства, про його зв'язки 3 іншими таємними організаціями, що діяли в Росії, Литві та Білорусії, а також про внутрішню боротьбу між шляхтою та демократами.

В такому ж дусі написана праця А. Бортникова «О связях А. Н. Кузьмина-Караваева с польскими революционными организациями» [3]. Автор у цій статті відмічає: «Основой солидарности руского и польського народов являлось то, что у них был один угнетатель и общий враг - царизм и крепостничество» [3, с. 161]. Дослідник розглядає участь у польських таємних організаціях передових російських офіцерів. Основна увага звернена на підпоручика Новоінгерманландського піхотного полку Кузьміна-Караваєва та його контакти із Ш. Конарським.

Значну роботу по розширенню джерельної бази щодо дослідження студентського руху у м. Києві та участь студентів у польському визвольному русі, провів А. Білан у роботі «Матеріали Київської секретної комісії про таємні товариства (1838 - 1839 рр.) та воєнно-слідчої комісії при Київському ордонанс-гаузі (1863 - 1865 рр.) як джерело історії революційно-демократичного руху в Київському університеті» [1]. Автор охарактеризував фонди 470 (Матеріали Київської секретної комісії про таємні товариства при Київському військовому, Подільському і Волинському генерал-губернаторі (1838 - 1839 рр.)) та 471 (Матеріали воєнно-слідчої комісії при Київському ордонанс-гаузі для розгляду справ учасників польського повстання (1863 - 1865 рр.)), що зберігаються у Центральному державному історичному архіві України у м. Києві [1, с. 112]. У статті коротко розглядається утворення київського студентського осередку за ініціативи активного учасника «Союзу польського народу» П. Боровського [1, с. 113], його склад та покарання, які понесли студенти за участь в акціях[1, с. 114]. Більше уваги автор приділив розгляду свідчень притягнутих до слідства студентів на основі яких можна визначити мету, склад, діяльність учасників та ін. [1, с. $117-120]$.

Над введенням до наукового обігу нових документів 3 даної проблеми працювала Г. Лебедєва. Вона у своїй роботі «Новые материалы о «Содружестве польского народа» и Шимоне Конарском [7], охарактеризувала документи, що зберігались у відділі письмових джерел Державного історичного музею в Москві. Ці документи в основному пов'язані 3 арештами, які масово розпочалися після затримання Ш. Конарського та наближених до 
ISSN 2518-1521 (Online), ISSN 2226-2830 (Print)

ВІСНИК МАРІУПОЛЬСЬКОГО ДЕРЖАВНОГО УНІВЕРСИТЕТУ

СЕРІЯ: ІСТОРІЯ. ПОЛІТОЛОГІЯ, 2019, ВИП. 25

нього осіб, їх допитами, а також які покарання отримали засудженні особи. Поряд із цим дослідниця проаналізувала листи та записки ув'язнених.

Наприкінці 60-х років дану проблему розпочав досліджувати Г. Марахов. Його дослідження продовжилися і протягом 70-х - поч. 80-х рр. Г. Марахов видрукував ряд досліджень про польський визвольний рух. Зокрема і праці, що стосуються діяльності Союзу польського народу: «Деятельность Содружества польского народана Правобережной Украине в 1835 - 1839 гг. (По материалам Киевского архива)» [8], «Социально-политическая борьба на Украине в 20 - 40-е годы XIX в.» [10], «Киевский университет в революционно-демократическом движении» [9].

У своїх роботах автор, на основі документів Київського архіву, подав інформацію про утворення, за сприяння польської еміграції в Західній Свропі, діяльність та викриття, російською владою, таємного товариства СПН під керівництвом Ш. Конарського на території Правобережної України [8, с. 166 - 194; 10, с. 80 - 98]. Автор детально проаналізував діяльність й інших таємних товариств, зокрема «Патріотичного товариства», яке мало девіз «Віра, Надія, Любов» і слугувало підгрунтям для утворення СПН; Жіночого таємного товариства на чолі з Свою Фелінською та осередку «Союзу польського народу» в Київському університеті [9, с. 17 - 23]. Автор детально вивчив програмні документи товариств окреслив їхню спільну діяльність, вказав, що на відміну від Волинської губернії у Подільській та Київській губерніях Ш. Конарський зустрів спротив та незгоду з боку поміщиків. Г.Марахов наголосив, що в статуті товариства не враховувались інтереси українського та білоруського народів. Проте, характерною особливістю організації «СПН» в Київському університеті було те, що в неї вступили й українці [8, с. 187].

Поряд із Г. Мараховим, детальну характеристику діяльності «СПН» на території України зробив у своїх роботах Г. Сергієнко. У 1969 р. була надрукована його стаття «Діяльність «Союзу польського народу» на Україні (1835-1839 рр.)» [12]. Більш широко це питання він розглянув у наступній своїй роботі «Суспільно-політичний рух на Україні після повстання декабристів. 1826-1850» [13, С. 113 - 175].

У роботах значна увага приділена діям польської еміграції після повстання 1830 1831 рр., яка розділилася на два табори - аристократичний на чолі з А. Чарторийським і революційно-демократичний під проводом Й. Лелевеля. Великий вплив мав міжнародний революційний рух. Утворення «Молодої Свропи» дало поштовх до виникнення «Молодої Польщі», яка мала безпосередній вплив на утворення та діяльність «СПН». «Молода Польща» - таємне товариство, що входило до складу «Молодої Європи» - міжнародної революційно-демократичної організації (1834 - 1836 рр.), метою якої було встановлення республіканського ладу в країнах Свропи. Її очолив італійський революціонер Джузеппе Мадзіні. До складу таємної організації входили ще такі таємні товариства: «Молода Італія», «Молода Німеччина», «Молода Франція», «Молода Іспанія», «Молода Швейцарія» $[13$, с. $115-116]$.

Оскільки Ш. Конарський був засновником «СПН» на українських землях, Г. Сергієнко подав біографічні дані діяча, проаналізував його статті та прокламацію «Голос вопіющого в пустелі», написану у формі звернення до поляків, назвав його одним 3 найактивніших учасників «Молодої Польщі» [13, с. 118 - 121]. Його конспіративна діяльність на Правобережній Україні знайшла детальне висвітлення в даній роботі. Крім цього автор, в більшій мірі ніж Г. Марахов, охарактеризував уже існуючі та новоутворені таємні товариства, які увійшли до складу «СПН», їхні програмні документи, які визначають мету завдання та принципи їх діяльності. Це такі як: Товариство 3 девізом 
ISSN 2518-1521 (Online), ISSN 2226-2830 (Print) ВІСНИК МАРІУПОЛЬСЬКОГО ДЕРЖАВНОГО УНІВЕРСИТЕТУ СЕРІЯ: ІСТОРІЯ. ПОЛІТОЛОГІЯ, 2019, ВИП. 25

«Віра, Надія, Любов» (Г. Марахов це товариство називає Патріотичним [8, с. 170]), що діяло на Волині, організація студентів Київського університету, Демократичне товариство в Одесі, Жіноче товариство на чолі з Свою Фелінською.

Аналізуючи статут СПН, автор наголосив, що одним 3 найголовніших завдань товариства була підготовка збройного повстання, участь у якому обов'язково мали взяти селяни, в тому числі й українські [13, с. 159 - 160]. Однією із найбільш слабких сторін у діяльності Ш. Конарського автор називає те, що визволення селян від кріпацтва він думав провести за бажанням самих поміщиків, проте останні нізащо не хотіли поступатися привілеями [13, с. 161]. 3-поміж іншого, автор розглядає і події пов'язані із європейським революційним рухом та місце у ньому «СПН» [13, с. 168].

Значний інтерес становить робота С. Дорошенка, котрий приділив увагу біографічним даним Ш. Конарського у статті «Польский революционер Шимон Конарский (1808 - 1839 рр.)» [4]. На його думку, у радянській історіографії, на відміну від польської, особа Ш.Конарського є маловідомою порівняно із своєю діяльністю, тому автор поставив за мету через особистість Ш. Конарського популяризувати ідеї боротьби за свободу пригноблених народів [4, с. 61]. Підводячи підсумки, автор зазначив: «Деятельность Конарского и его последователей внесла настроения братства в отношения с другими славянскими народами, способствовала распространению среди них идей равноправия» [4, c. 71].

У 1998 р. з'явилася робота українського історика Л. Іванової «Україна в польському національно-визвольному русі в $30-50$ роках XIX ст.» [5]. Якщо завданням радянських істориків було показати спільну боротьбу слов'янських народів проти російського самодержавства то у роботі Л. Іванової стверджується інше. Вона показала, що український національно-визвольний рух стояв осторонь польського, а в загострених ситуаціях виступав проти нього. Дослідниця стверджувала, що у 30-х роках XIX ст. головним завданням в національній програмі всіх таємних польських товариств на Україні стала проблема єдності поляків з українським населенням Правобережної України. За це виступав і Ш. Конарський, який стверджував, що лише за допомогою єдності усіх верств населення можна досягнути відновлення Речі Посполитої у кордонах 1772 р. Проте польська шляхта Правобережної України не розділяла радикальних методів демократичної партії, та відстоювала старі порядки. На думку дослідниці, ці демократичні ідеї могли б втілитися в реальність, проте завадило швидке викриття та знищення таємних організацій $[5$, c. $8-12]$.

Наукова література XXI століття характеризується тим, що основна увага дослідників звернена на репресивну політику російської влади проти польського елементу на Правобережній Україні після викриття СПН.

Так, сучасний фінський історик Й. Ремі, у статті «Імперська освітня політика і польське питання в Київському учбовому окрузі. Суперечка між Сергієм Уваровим та Дмитром Бібіковим наприкінці 1830-х рр.» [11] показав, що реакція російського уряду на діяльність в Київському університеті польської таємної організації члени якої належали до СПН була досить жорсткою. Оскільки відкриваючи університет, російська влада в ньому вбачала інструмент русифікації населення Правобережної України і не виправдавши цих сподівань влада приймає рішення закрити його, до прийняття кроків, які викорінять польський елемент з університету [11, с. 18].

Автор протиставляє політику генерал-губернатора Д. Бібікова (була радикальною, виступав за звільнення всіх вчителів-поляків, та тих котрі навчалися чи викладали в 
ISSN 2518-1521 (Online), ISSN 2226-2830 (Print)

ВІСНИК МАРІУПОЛЬСЬКОГО ДЕРЖАВНОГО УНІВЕРСИТЕТУ

СЕРІЯ: ІСТОРІЯ. ПОЛІТОЛОГІЯ, 2019, ВИП. 25

Кременецькому ліцеї, з забороною давати приватні уроки, за ними встановлювався нагляд) та міністра народної просвіти С. Уварова (поміркована, вважав причиною політичної активності в університеті зовнішню агітацію, і тому покарані мали бути лише активні учасники) [11, с. 18 - 19]. Проте царю ближчими були погляди Д. Бібікова. У результаті, як зазначає автор, викриття діяльності групи студентів Київського університету, що належали до СПН стало лише приводом до русифікаторської політики краю, проте кожен із чиновників бачив іï по своєму [11, с. 20].

Якщо Й. Ремі розглянув репресивні заходи російського уряду в освіті то українська дослідниця Ю. Хитровська звернула увагу на репресії проти духовних осіб. У своїй роботі «Участь католицького духовенства у діяльності польського таємного товариства «Співдружність польського народу» на Правобережній Україні та реакція на неї російського уряду» [18] вона зазначила, що лише ксьондз Яжина зізнався у своїх зв'язках iз таємною організацією всі інші заперечували свою причетність, проте до відповідальності були притягнуті всі духовні особи, які викликали найменші підозри та отримали важкі покарання, такі як заслання до Сибіру, конфіскація майна, позбавлення громадських прав та духовного сану і ін.

Поряд із участю у польському національному русі католицьких священників дослідниця підкреслює, що на їх погляди великий вплив мала масонська ідеологія [18].

Французький історик, Д. Бовуа, у своїй роботі ставив за мету показати невідповідність між масштабом патріотичної діяльності поляків на Правобережній Україні та репресивною діяльність на це зі сторони царської влади [2, с. 506]. За словами автора ідеї Ш. Конарського, щодо утворення незалежності Польщі на основі союзу з селянством не користувалась популярністю. Польська еміграція була далека від реальності і не враховувала етнічну різницю місцевого населення, тому i не знайшла масштабної підтримки. Про розбіжність ідей СПН від ідей селянства та національного питання зазначав і Й. Ремі [11, с. 17]. Д.Бовуа виділив основні заходи російського самодержавства спрямовані на придушення польської думки i польського політичного руху. Це конфіскація майна, заслання, страти, тюремне ув'язнення, ревізії, шпіонаж. На думку автора на території України ці заходи носили цілеспрямований та систематичний характер задля асиміляції польського населення [2, с. 518]. Автор вказав, що російська влада приймала жорсткі заходи, маючи найменші підозри: «без установления меры вины налагались секвестры на большую часть имений, принадлежащих подозреваемым лицам, их родственникам и однофамильцам» [2, с. 513]. Проте політика по конфіскації майна не дала бажаних результатів.

«Чиновник по особым поручениям был необходимым звеном «системы Бибикова», которая должна была превратить Украину в молчаливое царство, где каждый должен был стать жалким униженным существом, пытающимся скрыть свою горечь, ненависть и желание мести» [2, с. 517].

Наступним кроком у вивченні даної проблеми стала збірка «Stowarzyszenie Ludu Polskiego na Podolu, Wołyniu i w gubernii Kijowskiej. Szymon Konarski» [28], яка побачила світ у 2009 р. Вона підготовлена спільними силами Інституту історії ПАН, інституту літературних досліджень ПАН та інституту слов'янознавства РАН. Робота розділена на дві частини. В першій частині поміщені чотири статті польських та російських авторів.

Г. Макарова продовжуючи традицію досліджень істориків XXI ст. про заходи російської влади проти учасників СПН у статті «Политические меры российского правительства в отношении семей участников заговора Шимона Конарского (по архивным 
ISSN 2518-1521 (Online), ISSN 2226-2830 (Print) ВІСНИК МАРІУПОЛЬСЬКОГО ДЕРЖАВНОГО УНІВЕРСИТЕТУ СЕРІЯ: ІСТОРІЯ. ПОЛІТОЛОГІЯ, 2019, ВИП. 25

материалам)» [23] вказала, що Київський військовий генерал-губернатор Д. Бібіков наполягав на виселені разом із учасниками СПН їх сімей [23, с. 53 - 54], проте Комітет західних губерній, який займався цим питанням, проводив більш демократичну політику. На думку дослідниці, це пов'язано із тим, що жорстка політика російської влади після Листопадового повстання не дала позитивних результатів, тому влада шукала інші методи боротьби з польським визвольним рухом. Як зазначила автор російська влада в першу чергу спрямувала їх на польську молодь, допомагала дітям засуджених поляків у здобутті освіти [23, с. 65]. Проте враховуючи подальші події слід погодитися 3 автором, що ці заходи були малоефективними.

Є. Семенов розглянув господарську діяльність польських засуджених на Забайкаллі [26]. Дві інші статті розкривають історіографію питання. Е. Кіслак проаналізувала літературні твори, що стосуються даної теми [20], а Я. Тринковський охарактеризував щоденник Юліана Сабіньського [29].

Друга частина книги вміщує низку документів, які безпосередньо проливають світло на діяльність та викриття товариства. Серед них: програмні документи, зізнання, протоколи, вироки тощо. [28, с.131 - 581].

Отже, апогеєм дослідження даної теми польськими російськими та українськими дослідниками можна вважати другу половину XX ст. цьому сприяло відкриття архівних документів та завдання радянської історіографії. Польські історики розглядали СПН на Правобережжі у контексті загального польського національного руху, тоді як радянські деталізували діяльність СПН на Правобережній Україні, через те, що мали кращий доступ до архівів. Дослідники ж XXI століття звернули увагу на спротив українського населення проти польського визвольного руху, що суперечило як польській так і радянській ідеології XX століття, а також показали страх російської влади, яка на будь-які прояви національного руху використовувала найжорсткіші методи придушення.

Таким чином, комплексне монографічне дослідження проблем діяльності «Союзу польського народу» на території України відсутнє. I в українській і в радянській історіографії участь представників українського народу в діяльності цього товариства залишається недостатньо вивченою.

Основою для подальшого вивчення діяльності Союзу польського народу на території України може стати збірка «Stowarzyszenie Ludu Polskiego na Podolu, Wołyniu i w gubernii Kijowskiej. Szymon Konarski», що вміщує статті та документи, які проливають світло на дану проблему.

\section{Список використаної літератури}

1. Білан А. М. Матеріали Київської секретної комісії про таємні товариства (18381839 рр.) та воєнно-слідчої комісії при Київському ордонансгаузі (1863-1865 рр.) як джерело історії революційно-демократичного руху в Київському університеті / А. М. Білан // Вісник Київського університету. Серія: Історія. - 1968. - № 10. - С. 112 - 122 ; Bilan A. M. Materialy Kyivskoi sekretnoi komisii pro taiemni tovarystva (1838-1839 rr.) ta voienno-slidchoi komisii pry Kyivskomu ordonanshauzi (1863-1865 rr.) yak dzherelo istorii revoliutsiino-demokratychnoho rukhu v Kyivskomu universyteti / A. M. Bilan // Visnyk Kyivskoho universytetu. Seriia: Istoriia. - 1968. - № 10. - S. $112-122$.

2. Бовуа Д. Гордиев узел Российской империи: Власть, шляха и народ на Правобережной Украине (1793 - 1914) / Д. Бовуа; авториз. пер. с фр. М. Крисань. - Москва : Новое литературное обозрение, 2011. - 998 с. ; Bovua D. Gordiev uzel Rossiyskoy imperii: 
ISSN 2518-1521 (Online), ISSN 2226-2830 (Print)

ВІСНИК МАРІУПОЛЬСЬКОГО ДЕРЖАВНОГО УНІВЕРСИТЕТУ

СЕРІЯ: ІСТОРІЯ. ПОЛІТОЛОГІЯ, 2019, ВИП. 25

Vlast, shlyakha i narod na Pravoberezhnoy Ukraine (1793 - 1914) / D. Bovua; avtoriz. per. s fr. M. Krisan. - Moskva : Novoe literaturnoe obozrenie, 2011. - 998 s.

3. Бортников А. И. О связях А. Н. Кузьмина-Караваева с польскими революционными организациями / А. И. Бортников // Вопросы истории славян. - Воронеж : Издательство воронежского университета, 1966. - Вып. 2. - C. 161 - 173 ; Bortnikov A. I. O svyazyakh A. N. Kuzmina-Karavaeva s polskimi revolyutsionnymi organizatsiyami / A.I. Bortnikov // Voprosy istorii slavyan. - Voronezh : Izdatelstvo voronezhskogo universiteta, 1966. - Vyp. 2. - S. $161-173$.

4. Дорошенко Е. А. Польский революционер Шимон Конарский (1808-1839) / Е.А. Дорошенко // Вестник Московского университета. Сер. 8. История. - 1991. - № 6. C. 61-71 ; Doroshenko Ye. A. Polskiy revolyutsioner Shimon Konarskiy (1808-1839) /Ye.A. Doroshenko // Vestnik Moskovskogo universiteta. Ser. 8. Istoriya. - 1991. - № 6. S. 61-71.

5. Іванова Л. Г. Україна в польському національно-визвольному русі в 30 - 50 роках ХІХ ст. / Л. Г. Іванова. - Київ : Вид. Національного пед. університету ім. М.П. Драгоманова, 1998. - 22 с. ; Ivanova L. H. Ukraina v polskomu natsionalno-vyzvolnomu rusi v 30 - 50 rokakh XIX st. / L. H. Ivanova. - Kyiv : Vyd. Natsionalnoho ped. universytetu im. M. P. Drahomanova, 1998. - 22 s.

6. Кузьмин М. Н. Координационное совещание по актуальным проблемам славяноведения / М. Н. Кузьмин // Вопросы истории. - 1961. - № 6. - С. 111 - 114 ; Kuzmin M. N. Koordinatsionnoe soveshchanie po aktualnym problemam slavyanovedeniya / M. N. Kuzmin // Voprosy istorii. - 1961. - № 6. - S. 111 - 114.

7. Лебедева Г. М. Новые материалы о «Содружестве польского народа» и Шимоне Конарском / Г. М. Лебедева // Из истории общественно-политического движения в России XIX века: (Материалы отдела письменных источников Государственного исторического музея) - Москва : Советская Россия, 1967. - С. 5 - 33; Lebedeva G. M. Novye materialy o «Sodruzhestve polskogo naroda» i Shimone Konarskom / G. M. Lebedeva // Iz istorii obshchestvenno-politicheskogo dvizheniya v Rossii XIX veka: (Materialy otdela pismennykh istochnikov Gosudarstvennogo istoricheskogo muzeya) - Moskva : Sovetskaya Rossiya, 1967. S. $5-33$.

8. Марахов Г. И. Деятельность «Содружества польського народа» на Правобережной Украине в 1835-1839 гг. (по материалам Киевского архива) / Г.И. Марахов // Связи революционеров России и Польши XIX - начала XX вв. - Москва : Наука, 1968. - С. 166 194 ; Marakhov G. I. Deyatelnost «Sodruzhestva polskogo naroda» na Pravoberezhnoy Ukraine v 1835-1839 gg. (po materialam Kievskogo arkhiva) / G.I. Marakhov // Svyazi revolyutsionerov Rossii i Polshi XIX - nachala XX vv. - Moskva : Nauka, 1968. - S. 166 - 194.

9. Марахов Г. И. Киевский университет в революционно-демократическом движении / Г. И. Марахов. - Киев : Вища школа; Изд-во при Киев. ун-те, 1984. - 119 с. ; Marakhov G. I. Kievskiy universitet v revolyutsionno-demokraticheskom dvizhenii / G.I. Marakhov. - Kiev : Vishcha shkola; Izd-vo pri Kiev. un-te, 1984. - 119 s.

10. Марахов Г. И. Социально-политическая борьба на Украине в 20 - 40-е годы XIX в. / Г. И. Марахов. - Киев : Вища школа; Изд-во при Киев. ун-те, 1979. - 150 с. ; Marakhov G. I. Sotsialno-politicheskaya borba na Ukraine v 20 - 40-e gody XIX v. / G.I. Marakhov. - Kiev : Vishcha shkola; Izd-vo pri Kiev. un-te, 1979. - 150 s.

11. Ремі Й. Імперська освітня політика і польське питання в Київському учбовому окрузі. Суперечка між Сергієм Уваровим та Дмитром Бібіковим наприкінці 1830-х рр. 
ISSN 2518-1521 (Online), ISSN 2226-2830 (Print) ВІСНИК МАРІУПОЛЬСЬКОГО ДЕРЖАВНОГО УНІВЕРСИТЕТУ СЕРІЯ: ІСТОРІЯ. ПОЛІТОЛОГІЯ, 2019, ВИП. 25

/ Й. Ремі // Етнічна історія народів Європи. - 2001. - Вип. 8. - С. 17-21 ; Remi Y. Imperska osvitnia polityka i polske pytannia v Kyivskomu uchbovomu okruzi. Superechka mizh Serhiiem Uvarovym ta Dmytrom Bibikovym naprykintsi 1830-kh rr. / Y. Remi // Etnichna istoriia narodiv Yevropy. - 2001. - Vyp. 8. - S. 17-21.

12. Сергієнко Г. Я. Діяльність «Союзу польського народу» на Україні (1835-1839рр.) / Г. Я. Сергієнко // Український історичний журнал. - 1969. - № 12. - С. 75 - 84 ; Serhiienko H. Ya. Diialnist «Soiuzu polskoho narodu» na Ukraini (1835-1839 rr.) / H. Ya. Serhiienko // Ukrainskyi istorychnyi zhurnal. - 1969. - № 12. - S. $75-84$.

13. Сергієнко Г. Я. Суспільно-політичний рух на Україні після повстання декабристів. 1826 - 1850 / Г. Я. Сергієнко. - Київ : Наук. думка, 1971. - 300 с. ; Serhiienko H. Ya. Suspilno-politychnyi rukh na Ukraini pislia povstannia dekabrystiv. $1826-1850$ / H. Ya. Serhiienko. - Kyiv : Nauk. dumka, 1971. - 300 s.

14. Сімонов С. С. Осередок «Союзу польського народу» в Київському університеті / С. С. Сімонов // Вісник Київського університету. Серія історії і філософії. - 1961. - № 4, Вип. 1. - С. 89 - 102 ; Simonov S. S. Oseredok «Soiuzu polskoho narodu» v Kyivskomu universyteti / S. S. Simonov // Visnyk Kyivskoho universytetu. Seriia istorii i filosofii. - 1961. № 4, Vyp. 1. - S. $89-102$.

15. Смирнов А. Ф. Революционные связи народов России и Польши: 30-60 годы XIX века / А. Ф. Смирнов. - Москва : Соцэкгиз, 1962. - 425 с.; Smirnov А. F. Revolyutsionnye svyazi narodov Rossii i Polshi: 30-60 gody XIX veka / A. F. Smirnov. Moskva : Sotsekgiz, 1962. $-425 \mathrm{~s}$.

16. Хададова М. В. Діяльність «Союзу польського народу» в Правобережній Україні в радянській історіографії 60-х років XX ст. / М. В. Хададава // Матеріали III Волинської Міжнародної історико-краєзнавчої конференції 12-13 листопада 2010 р. - Житомир : Вид. ЖДУ ім. І.Франка, 2010. - С. 318 - 320 ; Khadadova M. V. Diialnist «Soiuzu polskoho narodu» v Pravoberezhnii Ukraini v radianskii istoriohrafii 60-kh rokiv XX st. / M.V. Khadadava // Materialy III Volynskoi Mizhnarodnoi istoryko-kraieznavchoi konferentsii 12-13 lystopada 2010 r. - Zhytomyr : Vyd. ZhDU im. I.Franka, 2010. - S. 318 - 320.

17. Хададова М. В. Діяльність «Союзу польського народу» на Правобережній Україні в радянській історіографії / М. В. Хададава // Волинські історичні записки : зб. наук. праць. - 2012. - T. 8. - C. 210 - 215 ; Khadadova M. V. Diialnist «Soiuzu polskoho narodu» na Pravoberezhnii Ukraini v radianskii istoriohrafii / M. V. Khadadava // Volynski istorychni zapysky : zb. nauk. prats. -2012 . - T. 8. - S. $210-215$.

18. Хитровська Ю. В. Участь католицького духовенства у діяльності польського таємного товариства «Співдружність польського народу» на Правобережній Україні та реакція на неї російського уряду [Електронний ресурс] / Ю. В. Хитровська // Materialy VI mezinarodni vedecko-prakticka conference «Nastoleni moderni vedy - 2007». - Praha, 2007. -
Dil 3.
S. 9-12.
Режим
доступу

http://www.rusnauka.com/15.PNR_2007/Istoria/21761.doc.htm ; Khytrovska Yu. V. Uchast katolytskoho dukhovenstva u diialnosti polskoho taiemnoho tovarystva «Spivdruzhnist polskoho narodu» na Pravoberezhnii Ukraini ta reaktsiia na nei rosiiskoho uriadu [Elektronnyi resurs] / Yu.V. Khytrovska // Materialy VI mezinarodni vedecko-prakticka conference «Nastoleni moderni vedy - 2007». - Praha, 2007. - Dil 3. - S. 9-12. - Rezhym dostupu : http://www.rusnauka.com/15.PNR_2007/Istoria/21761.doc.htm

19. Kieniewicz S. Konspiracje Galicyjskie (1831-1845) / S. Kieniewicz. - Warszawa : Książka i Wiedza, 1950. - 236 s. 
ISSN 2518-1521 (Online), ISSN 2226-2830 (Print)

ВІСНИК МАРІУПОЛЬСЬКОГО ДЕРЖАВНОГО УНІВЕРСИТЕТУ

СЕРІЯ: ІСТОРІЯ. ПОЛІТОЛОГІЯ, 2019, ВИП. 25

20. Kiślak E. Konarszczyzna w literaturze / E. Kiślak // Stowarzyszenie Ludu Polskiego na Podolu, Wołyniu i w gubernii Kijowskiej. SzymonKonarski / red. M. Micińska. - Warszawa, 2009. - S. $67-96$.

21. Łopuszański B. Stowarzyszenie Ludu Polskiego (1835 - 1841) / B. Łopuszański. Kraków, 1975. - 396 s.

22. Łukaszewicz W. Szymon Konarski (1808-1839) / W. Łukaszewicz. - Warszawa Spółdzielnia Wydawnicza «Książka», 1948. - 233 s.

23. Makarowa G. Политические меры российского правительства в отношении семей участников заговора Шимона Конарского (по архивным материалам) / G. Makarowa // Stowarzyszenie Ludu Polskiego na Podolu, Wołyniu i w gubernii Kijowskiej. SzymonKonarski / red. Magdalena Micińska. - Warszawa, 2009. - S. 51 - 65.

24. Mościcki H. Szymon Konarski / H. Mościcki. - Warszawa : Państwowy Instytut Wudawniczy, 1949. - 97 s.

25. Rozdolski R. Do historii «Stowarzyszenia Ludu Polskiego» / R. Rozdolski // Kwartalnik historyczny. - 1936. - R. 50. - S. 712-726.

26. Siemionow J. Działalność gospodarcz polskich przestępców politycznych na Zabajkalu w czterdziestych - pięćdziesiątych latach XIX w. / J. Siemionow // Stowarzyszenie Ludu Polskiego na Podolu, Wołyniu i w gubernii Kijowskiej. SzymonKonarski / red. M. Micińska. Warszawa, 2009. - S. 31. - 50.

27. Skowronek J. Od konspiracji do kapitulacji / J. Skowronek. - Warszawa, 1989. - 82 s.

28. Stowarzyszenie Ludu Polskiego na Podolu, Wołyniu i w gubernii Kijowskiej. SzymonKonarski / red. M. Micińska. - Warszawa, 2009. - 581 s.

29. Trynkowski J. Dziennik mojej niewoli i wygnania i jego autor - Julian Sabiński / J. Trynkowski // Stowarzyszenie Ludu Polskiego na Podolu, Wołyniu i w gubernii Kijowskiej. Szymon Konarski / red. . Micińska. - Warszawa, 2009. - S. 97 - 129.

Стаття надійшла до редакції 06.06.2019 р.

\section{Ju. Konarivska}

THE ACTIVITY OF THE «UNION OF THE POLISH PEOPLE» IN THE TERRITORY OF RIGHT-BANK UKRAINE IN THE HISTORICAL LITERATURE OF THE MIDDLE OF $20^{\text {TH }}$ - THE BEGINNING OF THE $21^{\text {ST }}$ CENTURY.

The works of historians of the $20^{\text {th }}$ - beginning of the $21^{\text {st }}$ century are analyzed in the article. It explores the forms and directions of the activities of the Polish secret society "Union of Polish People" in the territory of Right-Bank Ukraine, whose purpose was to prepare the local population, particularly the peasantry that were mainly Ukrainians, for the rebellion for the reestablishment of the Polish-Lithuanian Commonwealth within the confines of country in 1772 which meant the annexion of Right-Bank Ukraine and Galicia.

Having made a comprehensive analysis we can trace the tasks of science, the views of historians which varied and depended on different periods of time and nationalities of them, and also how well this issue has been studied in Polish, Russian and Ukrainian historiography.

Because of the fact that principally the activity of the Union of Polish People was to undermine the Russian imperial authorities, Russian historians concealed the scale of the Polish liberation movement and did not pay attention to this issue. Russian and Ukrainian historians of the Soviet period made a significant contribution to the study of this topic but because of the Soviet ideology they tried to link the Polish and Ukrainian national movements as a struggle against imperial authority. Pointing to the scale of the Polish liberation movement Polish 
ISSN 2518-1521 (Online), ISSN 2226-2830 (Print) ВІСНИК МАРІУПОЛЬСЬКОГО ДЕРЖАВНОГО УНІВЕРСИТЕТУ СЕРІЯ: ІСТОРІЯ. ПОЛІТОЛОГІЯ, 2019, ВИП. 25

historians tried to prove the belonging of Right-Bank Ukraine and Galicia to the PolishLithuanian Commonwealth and to justify the attempts of the Polish revolutionary forces to stir up a rebellion on these lands.

At the end of the $20^{\text {th }}$ century - at the beginning of the 21 st century the native and foreign historians are trying to assess the activity of the society objectively. However, there is still no comprehensive monographic study of the problem of the activity of the Union of Polish People in the territory of Ukraine. In 2009 Polish and Russian historians published a collection titled "Stowarzyszenie Ludu Polskiego na Podolu, Wotyniu $i$ w gubernii Kijowskiej. Szymon Konarski" which contained the articles and the documents that shed light on this problem. This collection may form the basis for further study of the activity of the Union of Polish People in the territory of Ukraine.

Key words: "Union of the Polish people», Polish liberation movement, Right-Bank Ukraine, historical literature of the $20^{\text {th }}$ - beginning of $21^{\text {st }}$ century.

УДК 930(477) : 929Грушевський

\section{Н. I. Романцова}

\section{СУЧАСНІ МЕТОДОЛОГІЧНІ ПІДХОДИ В ІСТОРІОГРАФІЧНОМУ ДОСЛІДЖЕННІ НАУКОВОЇ ДІЯЛЬНОСТІ М. ГРУШЕВСЬКОГО}

У статті висвітлюються сучасні методологічні аспекти історіографічних досліджень наукової діяльності М. Грушевського. Розглядаються історіографічні оцінки цьього питання у прачях українських та зарубіжних теоретиків історичного пізнання початку XXI cm. За рахунок ичього поглиблюється аналіз наукової спадщини видатного вченого. З'ясовано місче сучасної методологї в історіографічних дослідженнях наукової діяльності історика.

Ключові слова: сучасні методологічні підходи, історіографічні дослідження, М. Грушевський, постмодернізм, інтелектуальна історія.

DOI 10.34079/2226-2830-2019-9-25-49-56

Історіографічне пізнання наукової діяльності M. Грушевського обумовлює необхідність застосування модерних методологічних підходів. Це надає можливість більш глибокого історіографічного аналізу наукової проблеми, подолання екстенсивного характеру грушевськознавства. Розробка української історіографії наукової діяльності М. Грушевського грунтується на сучасній епістемологічній моделі.

Питання застосування сучасних методологічних підходів у дослідженні наукової діяльності М. Грушевського тією чи іншою мірою аналізували провідні українські грушевськознавці: Л. Зашкільняк [5, 6], В. Тельвак [13, 14], О. Ясь [17, 18, 19] та інші. Аналізуючи методологічні аспекти розвитку грушевськознавства, вони наголошували на необхідності застосування сучасних методологічних підходів, розвитку цього українознавчого напряму в контексті постмодернізму, інтелектуальної історії.

Науковий інтерес при висвітленні означеної теми становлять студії авторитетних українських та зарубіжних історіографів, теоретиків історичного пізнання, дослідників 